\section{Effects of Soaking Cucumber and Tomato Seeds in Paclobutrazol Solutions on Fruit Weight, Fruit Size, and Paclobutrazol Level in Fruits}

\author{
Stanislav V. Magnitskiy, ${ }^{1}$ Claudio C. Pasian, ${ }^{2}$ Mark A. Bennett, and \\ James D. Metzger \\ Department of Horticulture and Crop Science, The Ohio State University, \\ 2001 Fyffe Court, Columbus, OH 43210
}

Additional index words. Cucumis sativus, Solanum lycopersicum, seeds, fruits, plant growth regulator, mass spectrometric analysis

\begin{abstract}
Determination of plant growth regulator accumulation in fruits and vegetables for human consumption is an important safety issue even when it is applied to seeds. Paclobutrazol accumulated preferentially in the seedcoats when soaking cucumber (Cucumis sativus L., cv. Poinsett $76 \mathrm{SR}$ ) seeds in 1000 or $4000 \mathrm{mg} \cdot \mathrm{L}^{-1}$ paclobutrazol. Cucumber plants grown from seeds soaked in $1000 \mathrm{mg} \cdot \mathrm{L}^{-1}$ paclobutrazol had lower average fruit weights than the control plants. Individual fruit length in cucumber was reduced by $40 \%$ when seeds were soaked in $1000 \mathrm{mg} \cdot \mathrm{L}^{-1}$ paclobutrazol solutions for 180 minutes. Soaking tomato (Solanum lycopersicum $\mathrm{L}$., cv. Sun 6108 ) seeds in 0 to $1000 \mathrm{mg} \cdot \mathrm{L}^{-1}$ paclobutrazol did not reduce average fruit weight or diameter per treatment. Paclobutrazol residue was not detected in cucumber and tomato fruits harvested from plants grown from seeds soaked in $1000 \mathrm{mg} \cdot \mathrm{L}^{-1}$ paclobutrazol for 180 minutes. Soaking seeds in paclobutrazol solutions represents a promising method of applying plant growth regulators to tomato and cucumber without accumulation of paclobutrazol residue in fruits.
\end{abstract}

Application of plant growth regulators (PGRs) influences all stages of plant development, including flowering and maturation of seeds (Han and Kim, 1999; Pressman and Shaked, 1988). Synthetic inhibitors of gibberellin biosynthesis in plants (e.g., paclobutrazol) may increase (Nishizava, 1993) or reduce (Knurshid et al., 1999) fruit yield when applied to plants as soil or foliar treatments. However, current regulations of the U.S. Environmental Protection Agency (EPA) prohibit paclobutrazol applications to vegetables (EPA, 2004). Other countries and institutions mandate maximum residual levels of paclobutrazol at $0.5 \mathrm{mg} \cdot \mathrm{kg}^{-1}$ in apples (Food and Agriculture Organization of the United Nations), $0.01 \mathrm{mg} \cdot \mathrm{kg}^{-1}$ in stone fruits (Australia), or $0.5 \mathrm{mg} \cdot \mathrm{kg}^{-1}$ in dry beans and small berries (Thailand) (EPA, 2004). These levels have been established

\footnotetext{
Received for publication 15 May 2006. Accepted for publication 26 June 2006. We thank Mrs. Monica Kmetz-Gonzalez for assistance with growing plants, Dr. Kari Green-Church and Mrs. Nan Kleinholz at the Chemical Instrumentation Center, The Ohio State University, for help with mass spectrometry analysis of paclobutrazol residue in plant samples, and Mr. Bert Bishop for assistance in data analysis.

${ }^{1}$ Current address: Dept. of Agronomy, National Univ. of Colombia, Building 500, Bogotá, Colombia.

${ }^{2}$ To whom reprint requests should be addressed; e-mail pasian.1@osu.edu.
}

based on analysis of plants subjected to soil or foliar paclobutrazol applications (Davis et al., 1988; Singh and Ram, 2000).

Presoaking seeds with PGRs is an alternative method of PGR application to plants (Pasian and Bennett, 2001; Pill and Gunter, 2001; Still and Pill, 2003). Soaking seeds in 50 (Still and Pill, 2006) or 500 (Pasian and Bennett, 2001) $\mathrm{mg} \cdot \mathrm{L}^{-1}$ paclobutrazol effectively controlled plug height in tomato, whereas soaking seeds in $500 \mathrm{mg} \cdot \mathrm{L}^{-1}$ paclobutrazol was the most effective treatment in growth retardation of cucumber (Cho et al., 2002). However, there are no available data on how treating seeds with paclobutrazol affects fruit weight and paclobutrazol level in fruits. Quantitative analysis of PGR accumulation in fruits harvested on plants grown from PGR-treated seeds allows determination of whether this application method is suitable for food destined for human consumption. Measuring paclobutrazol level in fruits would also help to clarify the movement of seed-associated PGR into plants during and after seed germination. The objectives of the present study were 1) to determine whether tomato and cucumber fruits harvested from plants obtained from paclobutrazol-treated seeds had any detectable growth regulator residue and 2) to determine the effect of soaking tomato and cucumber seeds in paclobutrazol solutions on fruit weight and size.
Plant materials and chemicals. The plant growth regulator used in this study was paclobutrazol ( $\beta$-[(4-chlorphenyl)methyl]$\alpha$-(1,1-dimethylethyl)-1H-1,2,4-triazole-1ethanol) in the Bonzi formulation (Syngenta Crop Protection, Greensboro, N.C.) containing $0.4 \%$ a.i.

Seed soaking. Tomato or cucumber seeds were soaked in water solutions of $0,50,200$, 500 , or $1000 \mathrm{mg} \cdot \mathrm{L}^{-1}$ paclobutrazol for 5 , 45 , or $180 \mathrm{~min}$ at $20{ }^{\circ} \mathrm{C}$, whereas untreated (nonsoaked) seeds represented the controls. For mass spectrometric analysis (LC- MS) only, cucumber seeds were soaked in 0,1000 , or $4000 \mathrm{mg} \cdot \mathrm{L}^{-1}$ paclobutrazol solutions for 5 or $180 \mathrm{~min}$. In each treatment, 100 seeds were placed in a glass beaker with 50 (tomato) or 100 (cucumber) $\mathrm{mL}$ paclobutrazol solution or water. While soaking the seeds, the beakers were constantly agitated $(40 \mathrm{rpm})$ on an orbital shaker Koala-Ty AP06502 (Accurate Chemical and Scientific Corp., Westbury, N.Y.). After soaking, seeds were transferred to a sieve and then dried on the surface of a filter paper (Whatman International Ltd., Maidstone, U.K.) for $24 \mathrm{~h}$ on an open bench at $20^{\circ} \mathrm{C}$.

Plant growth. Within 2 to $4 \mathrm{~d}$ after treatment application, tomato or cucumber seeds were sown one seed per cell in plastic 288 (5.9$\mathrm{cm}^{3}$ volume) or 164-cell $\left(9.7-\mathrm{cm}^{3}\right.$ volume) plug trays, respectively, filled with plug growth media Sunshine LP5 (Sun Gro Horticulture, Bellevue, Wash.). Each treatment consisted of 100 seeds divided into four replicates of 25 seeds each. Each replicate was randomly distributed within the plug trays. Seeds were covered with a small portion (5-mm depth) of the same substrate and placed under intermittent mist at $25^{\circ} \mathrm{C}$ for $1 \mathrm{~d}$. Plug trays were then moved to a $25^{\circ} \mathrm{C}$ greenhouse at The Ohio State Univ., Columbus, and randomly arranged on a wet capillary mat under natural central Ohio summer conditions. Plugs were watered as needed with municipal water and fertilized with a Peters Professional water-soluble fertilizer 20N-8.7P-16.7K (Scotts-Sierra Horticultural Products Co., Marysville, Ohio) at a rate of $2 \mathrm{~g} \cdot \mathrm{L}^{-1}$ every third irrigation.

At 33 or $34 \mathrm{~d}$ after planting (DAP) of cucumber or tomato, respectively, subsamples of eight plants were randomly selected in each treatment and transplanted into $3.8-\mathrm{L}$ plastic containers (one plant per container) filled with Metro-Mix 360 (The Scotts Co.). Flower number was estimated in five plants of each treatment of cucumber and tomato. Commercially mature fruits having yellow tips (cucumber) or pink color (tomato) were manually harvested in 7-d intervals from 40 to 68 DAP (cucumber) or in 10-d intervals from 62 to 92 DAP (tomato). Fruit weight and length of all fresh fruits in tomato and cucumber were manually measured at harvest. Fresh fruits were stored at $-18^{\circ} \mathrm{C}$ for further measurements of paclobutrazol residues.

Quantitative analysis of paclobutrazol in plant tissues. Cucumber seeds were manually separated into the seedcoats and the rest of the seed (embryonic axis plus cotyledons). Seed 
samples consisting of 5 to 8-g seedcoats and 22 to $26 \mathrm{~g}$ of decoated seed parts were used for paclobutrazol extraction. Fruits obtained from seed treatments with the lowest $\left(0 \mathrm{mg} \cdot \mathrm{L}^{-1}\right)$ and highest $\left(1000 \mathrm{mg} \cdot \mathrm{L}^{-1}\right)$ paclobutrazol rates were analyzed in both crops. For paclobutrazol analysis, fruits were randomly selected from different plants of each treatment. Each treatment was analyzed in three replicates with each replicate represented by an individual fruit of tomato or cucumber. Paclobutrazol was extracted from seeds or fruits according to the protocol developed by Jia et al. (2001). All samples were homogenized and extracted twice using a blender with $200 \mathrm{~mL}$ methanol/ water $(75 / 25, \mathrm{v} / \mathrm{v} \%)$ and $1.5 \mathrm{~mL} \mathrm{H}_{2} \mathrm{SO}_{4}$ for 10 min. The combined extracts were filtered through Celite 545. The Celite 545 cakes with plant residues were washed with $20 \mathrm{~mL}$ of the same solvent mixture. The filtrates were concentrated to 50 to $60 \mathrm{~mL}$ on a vacuum rotary evaporator under reduced pressure at $45{ }^{\circ} \mathrm{C}$ and cleaned out from the precipitates by suction. The filtrates were adjusted to $\mathrm{pH} 10$ with $2.0 \mathrm{M} \mathrm{KOH}$ and centrifuged at $6000 \mathrm{rpm}$ for $15 \mathrm{~min}$. The supernatant was aspirated and twice subjected to liquid-liquid extraction with equal volume of methylene chloride. The organic phase was separated, evaporated, dissolved in $2 \mathrm{~mL}$ cyclohexane/ether $(50 / 50, \mathrm{v} / \mathrm{v}$ $\%$, and applied to a $10.5-\mathrm{mm}$ i.d. glass column packed with $10 \mathrm{~g}$ Florisil $(0.15-0.25-\mathrm{mm}$ particle size, $5 \%$ deactivated) (Fisher Scientific, Fair Lawn, N.J.). The elution scheme for fraction cleanup on Florisil column at 2.5 $\mathrm{mL} \cdot \mathrm{min}^{-1}$ was: 1) $25 \mathrm{~mL}$ ether/cyclohexane (50/50, v/v \%); 2) $25 \mathrm{~mL}$ ether; and 3) $25 \mathrm{~mL}$ ether/methanol $(96 / 4, v / v \%)$. The last fraction was collected, evaporated to 100 to $200 \mu \mathrm{L}$, dissolved in $200 \mu \mathrm{L}$ acetonitrile/water (35/65, $\mathrm{v} / \mathrm{v} \%$ ), and subjected to combined liquid chromatography-mass spectrometry at the OSU Campus Chemical Instrument Center, Columbus. The liquid chromatographic/autosampler system consisted of a Waters Alliance 2690 Separations Module (Waters, Milford, Mass). A $1.0 \times 250-\mathrm{mm} \mathrm{C}_{18}$ column was used. The mobile phase was acetonitrile/water (35/ $65, \mathrm{v} / \mathrm{v} \%$ ) with $0.1 \%$ formic acid. The flow rate was $0.05 \mathrm{~mL} \cdot \mathrm{min}^{-1}$. The eluant from the column was injected directly into the Micromass LC-Tof II (Micromass, Wythenshawe, U.K.) mass spectrometer equipped with an orthogonal electrospray source (Z-spray) operated in the positive ion mode. Sodium iodide was used for mass calibration in a range of 100 to $2000 \mathrm{~m} / \mathrm{z}$. Optimal electrospray ionization conditions were $3000 \mathrm{~V}$ capillary voltage, 110 ${ }^{\circ} \mathrm{C}$ source temperature, and $55 \mathrm{~V}$ cone voltage. The ionization gas was nitrogen. All ions transmitted into the TOF analyzer were scanned with a 1-second integration time and data were acquired in continuous mode during the LC run. Analytical grade imidacloprid (1-[(6-chloro-3-pyridinyl)methyl]- $N$-nitro2-imidazolidinimine) was used as an internal standard. Preliminary data indicated that up to $90 \%$ paclobutrazol was extracted from the plants when using the sample preparation procedure described in this research (data not shown).
Paclobutrazol concentrations $\left(\mathrm{mg} \cdot \mathrm{kg}^{-1}\right.$ DW) were measured in the seedcoats and decoated seeds and used to calculate paclobutrazol amounts (milligrams per dry weight of seed part) in the seedcoats and decoated seeds. The latter amounts were added to receive paclobutrazol amount (milligrams per dry weight of one seed) in whole seeds, which was further used to calculate paclobutrazol concentration ( $\left.\mathrm{mg} \cdot \mathrm{kg}^{-1} \mathrm{DW}\right)$ in whole seeds. Dry weight of seeds was determined by drying seed parts at $60{ }^{\circ} \mathrm{C}$ for 48 hours.

Statistical analysis. Paclobutrazol level in seeds or fruits, total fruit yield, average fruit weight, and fruit length or diameter as a response to paclobutrazol concentration and soaking time were analyzed to test for significant linear effects using regression analysis with the general linear model procedure in SAS (SAS Institute, Cary, N.C.). Mean comparisons by $t$ test were used to evaluate the effect of water treatments (water-treated seeds vs. untreated seeds) on total fruit yield, average fruit weight, and fruit length or diameter.

\section{Results}

Paclobutrazol levels in cucumber seeds and fruits of cucumber and tomato. LC-MS analysis revealed that paclobutrazol accumulated preferentially in the seedcoats (Table 1). Paclobutrazol concentrations increased in all seed parts when seeds were soaked during longer times. However, for the highest concentration (4000 $\mathrm{mg} \cdot \mathrm{L}^{-1}$ paclobutrazol) tested, the ratio between paclobutrazol concentration in the seedcoats and the rest of the seed decreased from $\approx 70$ to 17 with increasing soaking time from 5 to $180 \mathrm{~min}$ (Table 1). Paclobutrazol was not detected by LC-MS in cucumber or tomato fruits harvested on plants grown from seeds soaked in 1000 $\mathrm{mg} \cdot \mathrm{L}^{-1}$ paclobutrazol solution for $180 \mathrm{~min}$ (data not shown).

Seedling emergence percentages in each treatment were $95 \%$ or $90 \%$ for cucumber or tomato, respectively. No differences in seedling emergence percentages between seeds treated with various paclobutrazol rates were found (data not shown).

Fruit weight, length, and diameter. When cucumber plants were grown from seeds treated with the highest paclobutrazol rates, flowering was delayed by $\approx 7$ to $10 \mathrm{~d}$. Increase in paclobutrazol concentration was associated with a reduction in average fruit weight or fruit length (Table 2) of cucumber when seeds were soaked for 5 or $180 \mathrm{~min}$, but not $45 \mathrm{~min}$. Fruit length (Table 2) was reduced by $40 \%$ when planting seeds soaked in $1000 \mathrm{mg} \cdot \mathrm{L}^{-1}$ paclobutrazol solution for $180 \mathrm{~min}$ as compared with water-soaked seeds. When cucumber seeds were treated with increasing paclobutrazol rates, no harvest-ready fruits were present for some treatments indicating delays in fruit maturation (data not shown). Flowering and fruit maturation were not delayed (data not shown), and fruit weight and diameter were unaffected in tomato plants grown from seeds soaked in paclobutrazol (Table 3).

\section{Discussion}

Quantitative analysis by LC-MS demonstrated that paclobutrazol penetrated cucumber seedcoats during seed soaking. The data in Table 1 indicate that the seedcoats inhibited paclobutrazol penetration into seeds mainly during a short soaking period (5 min). Soaking cucumber seeds for a longer time (180 $\mathrm{min})$ reduced the difference between paclobutrazol concentration in the seedcoats and the rest of the seed.

Table 1. Paclobutrazol concentration $\left(\mathrm{mg} \cdot \mathrm{kg}^{-1} \mathrm{DW}\right)$ in cucumber seedcoats and the rest of the seed (embryonic axis plus cotyledons) measured by mass spectrometry. ${ }^{z}$

\begin{tabular}{|c|c|c|c|c|c|c|c|c|c|}
\hline \multirow[b]{2}{*}{ Treatment } & \multicolumn{2}{|c|}{ Seed coats } & \multirow[b]{2}{*}{$L^{x}$} & \multicolumn{2}{|c|}{ Rest of the seed } & \multirow[b]{2}{*}{$L^{x}$} & \multicolumn{2}{|c|}{ Whole seed } & \multirow[b]{2}{*}{$L^{x}$} \\
\hline & $5 \min$ & $180 \mathrm{~min}$ & & $5 \mathrm{~min}$ & $180 \mathrm{~min}$ & & $5 \mathrm{~min}$ & $180 \mathrm{~min}$ & \\
\hline $0 \mathrm{mg} \cdot \mathrm{L}^{-1}$ & ND & ND & & ND & ND & & ND & ND & \\
\hline $1000 \mathrm{mg} \cdot \mathrm{L}^{-1}$ & 0.106 & 0.208 & y & 0.002 & 0.012 & $\mathrm{y}$ & 0.022 & 0.060 & $\mathrm{y}$ \\
\hline $4000 \mathrm{mg} \cdot \mathrm{L}^{-1}$ & 0.419 & 0.716 & $\mathrm{x}$ & 0.006 & 0.042 & $\mathrm{y}$ & 0.100 & 0.192 & $\mathrm{y}$ \\
\hline$L^{y}$ & $\mathrm{y}$ & $\mathrm{y}$ & & $\mathrm{x}$ & y & & y & $\mathrm{x}$ & \\
\hline Untreated & \multicolumn{2}{|c|}{ ND } & & \multicolumn{2}{|c|}{ ND } & & \multicolumn{2}{|c|}{ ND } & \\
\hline
\end{tabular}

${ }^{2}$ Seeds were soaked in 0,1000 , or $4000 \mathrm{mg} \cdot \mathrm{L}^{-1}$ paclobutrazol solutions for 5 or $180 \mathrm{~min}$, dried, and manually separated into parts.

${ }_{\mathrm{y}, \mathrm{x}}$ Significant at $P \leq 0.001, \leq 0.01$, respectively.

$\mathrm{L}^{\mathrm{x}}, \mathrm{L}^{\mathrm{y}}$, Linear models for the soaking time and paclobutrazol concentration effects, respectively. $\mathrm{ND}$, nondetectable amounts.

Table 2. Average cucumber fruit fresh weight $(\mathrm{g})$ and fruit length $(\mathrm{mm})$ of plants grown from seeds soaked in $0,50,200,500$, or $1000 \mathrm{mg} \cdot \mathrm{L}^{-1}$ paclobutrazol solutions for 5 , 45 , or $180 \mathrm{~min}^{\mathrm{z}}$

\begin{tabular}{|c|c|c|c|c|c|c|c|c|}
\hline \multirow[b]{2}{*}{ Treatment } & \multicolumn{3}{|c|}{ Fruit fresh wt (g) } & \multirow[b]{2}{*}{$\mathrm{L}^{\mathrm{x}}$} & \multicolumn{3}{|c|}{ Fruit length $(\mathrm{mm})$} & \multirow[b]{2}{*}{$\mathrm{L}^{\mathrm{x}}$} \\
\hline & $5 \mathrm{~min}$ & $45 \mathrm{~min}$ & $180 \mathrm{~min}$ & & $5 \mathrm{~min}$ & $45 \mathrm{~min}$ & $180 \mathrm{~min}$ & \\
\hline $0 \mathrm{mg} \cdot \mathrm{L}^{-1}$ & 258 & 234 & 277 & NS & 210 & 220 & 182 & $\overline{\mathrm{NS}}$ \\
\hline $50 \mathrm{mg} \cdot \mathrm{L}^{-1}$ & 253 & 275 & 222 & NS & 200 & 208 & 206 & NS \\
\hline $200 \mathrm{mg} \cdot \mathrm{L}^{-1}$ & 248 & 246 & 252 & NS & 218 & 226 & 186 & NS \\
\hline $500 \mathrm{mg} \cdot \mathrm{L}^{-1}$ & 202 & 250 & 210 & NS & 182 & 202 & 152 & NS \\
\hline $1000 \mathrm{mg} \cdot \mathrm{L}^{-1}$ & 163 & 283 & 196 & NS & 168 & 182 & 110 & $*$ \\
\hline $\mathrm{L}^{\mathrm{y}}$ & $* *$ & NS & $*$ & & $*$ & NS & $* *$ & \\
\hline Untreated & 252 & 240 & 262 & & 204 & 216 & 194 & \\
\hline
\end{tabular}

${ }^{\mathrm{z}}$ Fruits were harvested from 40 to $68 \mathrm{~d}$ after planting.

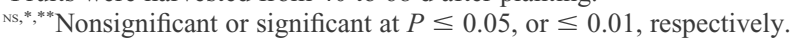


Soaking seeds in 250 to $2000 \mathrm{mg} \cdot \mathrm{L}^{-1}$ paclobutrazol inhibited not only seedling growth (Cho et al., 2002), but also flowering and fruit growth in cucumber, which might be associated with inhibition of GA biosynthesis. Delays in flowering resulting from inhibition of GA biosynthesis were earlier reported in sunflower and almond plants sprayed with paclobutrazol solutions (Almeida and Pereira, 1996; Koukourikou-Petridou, 1996). Reduction in fruit yield in paclobutrazol-treated plants was also likely incited by inhibition of GA biosynthesis (Davis et al., 1988).

An important question to be answered is whether paclobutrazol was present in plant tissue at the time when flowering and fruit maturation were delayed. LC-MS analysis indicates that paclobutrazol was not present in fruits or its concentration was below the detection limit of $0.025 \mathrm{mg} \cdot \mathrm{kg}^{-1} \mathrm{DM}$. Therefore, reductions in fruit weight or length were likely the result of action of paclobutrazol at the level of seeds or seedlings rather than at later stages of plant growth. Delays in flowering and reduced fruit weight were observed after transplanting plants into a new growing medium indicating that paclobutrazol was not located in the substrate. However, it cannot be excluded that at the time of flowering and fruit growth, paclobutrazol was present in the stems, leaves, or rhizosphere.

It can be concluded that seeds soaked in paclobutrazol solutions did not absorb and retain a significant amount of paclobutrazol to be retained in fruit. In paclobutrazol-treated seeds, embryo-associated paclobutrazol remains in closer proximity to the vascular system of embryonic axis than coat-located paclobutrazol. Therefore, paclobutrazol transport from internal seed parts into the shoot may begin directly from the embryonic phloem. However, the amount of paclobutrazol in the internal seed parts (Table 1) did not exceed the paclobutrazol detection limit of $0.025 \mathrm{mg} \cdot \mathrm{kg}^{-1} \mathrm{DM}$ fruit and, therefore, could not significantly contribute to paclobutrazol accumulation in fruits.

It is possible that coat-located paclobutrazol - the main potential source of paclobutrazol in cucumber seeds (Table 1)-diffused from the seedcoats into substrate and was absorbed by the root (Pasian and Bennett, 2001). However, further paclobutrazol movement from roots into fruits through xylem seems to be insignificant as a result of the small contribution of xylem sap to fruit growth (Ho and Adams, 1994). Additionally, small fruits had lower sink demand and less xylem area in the pedicel as compared with large fruits (Starck et al., 1990). Therefore, low accumulation of paclobutrazol through xylem could be expected in small cucumber fruits such as those collected from plants grown from seeds treated with increased paclobutrazol rates (Table 1). Rootabsorbed paclobutrazol may also move from the xylem to phloem and eventually penetrate into fruits (Singh and Ram, 2000). However, phloem-xylem connections in roots (Steudle and Peterson, 1998), stems (Welbaum and Meinzer, 1990), and fruits (Patrick, 1997) would likely contribute to losses of paclobutrazol during its movement from the xylem into the phloem. After entering the phloem, paclobutrazol would be unlikely transported into fruits in sufficient amounts, because it is characterized by limited phloem mobility (Davis et al., 1988; Fletcher et al., 2000). Therefore, both locations and concentration patterns of paclobutrazol in cucumber seeds (Table 1) provided unfavorable conditions for paclobutrazol accumulation in fruits. Tomato seeds have smaller volume and surface area than cucumber seeds and, therefore, may carry even less paclobutrazol amount than cucumber seeds when treated with the same paclobutrazol rates.

It could be concluded (Table 1) that cucumber seeds soaked in $200 \mathrm{mg} \cdot \mathrm{L}^{-1}$ paclobutrazol for 180 min may accumulate $\approx 0.016 \mathrm{mg} \cdot \mathrm{kg}^{-1} \mathrm{DW}$ paclobutrazol. Soaking seeds in such paclobutrazol rate is suggested for effective plug height control in cucumber (Cho et al., 2002) or tomato (Pasian and Bennett, 2001). Results of our study correspond well to international standards establishing zero tolerance for paclobutrazol residue in fruits (EPA, 2004). Therefore, soaking seeds in paclobutrazol solutions represents a promising method of controlling plug height of tomato and cucumber without accumulation of paclobutrazol residue in fruits.

\section{Literature Cited}

Almeida, J.A.S. and M.F.D.A. Pereira. 1996. The control of flower initiation by gibberellin in Helianthus annus L. (sunflower), a nonphotoperiodic plant. Plant Growth Regulat. 19:109-115.

Cho, K.C., W.M. Yang, W.S. Kim, and S.J. Chung. 2002. Growth retardation of cucumber (Cucumus sativus L.) seedlings by treatment of

Table 3. Average tomato fruit fresh weight $(\mathrm{g})$ and fruit diameter $(\mathrm{mm})$ of plants grown from seeds soaked in $0,50,200,500$, or $1000 \mathrm{mg} \cdot \mathrm{L}^{-1}$ paclobutrazol solutions for 5,45 , or $180 \mathrm{~min} .{ }^{2}$

\begin{tabular}{|c|c|c|c|c|c|c|c|c|}
\hline \multirow[b]{2}{*}{ Treatment } & \multicolumn{3}{|c|}{ Fruit fresh wt (g) } & \multirow[b]{2}{*}{$\mathrm{L}^{\mathrm{x}}$} & \multicolumn{3}{|c|}{ Fruit diam $(\mathrm{mm})$} & \multirow[b]{2}{*}{$L^{x}$} \\
\hline & $5 \mathrm{~min}$ & $45 \mathrm{~min}$ & $180 \mathrm{~min}$ & & $5 \min$ & $45 \mathrm{~min}$ & $180 \mathrm{~min}$ & \\
\hline $0 \mathrm{mg} \cdot \mathrm{L}^{-1}$ & 169 & 141 & 158 & NS & 52 & 54 & 56 & $\overline{\mathrm{NS}}$ \\
\hline $50 \mathrm{mg} \cdot \mathrm{L}^{-1}$ & 158 & 136 & 124 & NS & 54 & 56 & 54 & NS \\
\hline $200 \mathrm{mg} \cdot \mathrm{L}^{-1}$ & 137 & 126 & 138 & NS & 56 & 54 & 54 & NS \\
\hline $500 \mathrm{mg} \cdot \mathrm{L}^{-1}$ & 134 & 125 & 138 & NS & 52 & 58 & 56 & NS \\
\hline $1000 \mathrm{mg} \cdot \mathrm{L}^{-1}$ & 152 & 150 & 158 & NS & 56 & 56 & 53 & NS \\
\hline $\mathrm{L}^{\mathrm{y}}$ & NS & NS & NS & & NS & NS & NS & \\
\hline Untreated & 162 & 140 & 150 & & 52 & 56 & 54 & \\
\hline
\end{tabular}

${ }^{\mathrm{z}}$ Fruits were harvested from 62 to $92 \mathrm{~d}$ after planting.

$\mathrm{L}^{\mathrm{x}}, \mathrm{L}^{\mathrm{y}}$ : Linear models for the soaking time and paclobutrazol concentration effects, respectively ${ }^{\mathrm{N}}$ Nonsignificant. paclobutrazol and removal of retardation by foliar spray of gibberellin. J. Korean Soc. Hort. Sci. 43:415-420.

Davis, T.D., G.L. Steffens, and N. Sankhla. 1988 Triazole plant growth regulators. Hort. Rev. (Amer. Soc. Hort. Sci.) 10:63-105.

EPA. US Environmental Protection Agency. 2004 http://www.epa.gov.

Fletcher, A., A. Gilley, N. Sankhla, and T. Davies. 2000. Triazoles as plant growth regulators and stress protectants. Hort. Rev. (Amer. Soc. Hort. Sci.) 24:55-138.

Han, I.S. and J.G. Kim. 1999. Effects of growth regulators on growth, flowering, and germination of harvested seeds in Clinopodium chinense var. parviflorum. J. Korean Soc. Hort. Sci. 40:765-768

Ho, L.C. and P. Adams. 1994. The physiological basis for the high fruit yield and susceptibility to calcium deficiency in tomato and cucumber J. Hort. Sci. 69:367-376.

Jia, M., W.Y. Feng, C.C. Pasian, and J.D. Metzger. 2001. A highly sensitive and specific LC/MS/ MS method for simultaneous quantitation of three systemic chemicals in ornamental plants. Proceedings of the 49th ASMS Conference on Mass Spectometry and Allied Topics, Chicago, Ill, May 27-31, 2001

Knurshid, T., D.L. McNeil, and M.C.T. Trought 1999. Effect of foliar-applied gibberellins and soil-applied paclobutrazol on reproductive and vegetative growth of Braeburn' apple trees growing under a high density planting system. New Zeal. J. Crop Hort. Sci. 25:49-58.

Koukourikou-Petridou, M.A. 1996. Paclobutrazol affects growth of almond fruits and germination of almond seeds. Plant Growth Reg. 20:267-269.

Nishizava, T. 1993. The effect of paclobutrazol on growth and yield during first year greenhouse strawberry production. Sci. Hort. (Amsterdam) 54:267-274.

Pasian, C.C. and M. Bennett. 2001. Paclobutrazol soaked marigold, geranium, and tomato seeds produce short seedlings. HortSci. 36:721-731.

Patrick, J.W. 1997. Phloem unloading: sieve element unloading and post-sieve element transport. Ann. Rev. Plant Physiol. Plant Molec. Biol. 48:191-222.

Pill, W.G. and J.A. Gunter. 2001. Emergence and shoot growth of cosmos and marigold from paclobutrazol-treated seed. J. Env. Hort. 19:11-14.

Pressman, E. and R. Shaked. 1988. Germination of annual celery Apium graveolens seeds inhibition by paclobutrazol and its reversal by gibberellins and benzyladenine. Physiol. Plant. 73:323-326.

Singh, D.K. and S. Ram. 2000. Level of paclobutrazol residues in shoot and fruit of mango. Indian J. Plant Physiol. 5:186-188.

Starck, Z., Z. Wazynska, O. Kucewicz, and B. Witek-Czuprunska. 1990. Relationship between fruit growth and anatomical structure of pedicels in tomato plants treated with growth regulators. Acta Physiol. Plant 12:59-66.

Steudle, E. and C.A. Peterson. 1998. How does water get through roots? J. Exp. Bot. 49:775-788.

Still, J.R. and W.G. Pill. 2003. Germination, emergence, and seedling growth of tomato and impatiens in response to seed treatment with paclobutrazol. HortScience. 38:1201-1204.

Still, J.R. and W.G. Pill. 2006. Growth and stress tolerance of tomato seedlings (Lycopersicon esculentum Mill.) in response to seed treatment with paclobutrazol. J. Hort. Sci. Biotechnol. 81:197-203.

Welbaum, G.E. and F.C. Meinzer. 1990. Compartmentalization of solutes and water in developing sugarcane stalk tissue. Plant Physiol. 93:1147-1153. 